\title{
Shifting the Threshold of Public Space in UK, Algeria and Mexico during the Covid-I9 Pandemic
}

\author{
Barbora Melis \\ University of Portsmouth, United Kingdom \\ barbora.melis@port.ac.uk \\ Jose Antonio Lara Hernandez \\ Universidad Marista de Merida, Mexico \\ joselarah@p.marista.edu.mx \\ Yazid Mohammed Khemri, Alessandro Melis
University of Portsmouth, United Kingdom
yazid.khemri@port.ac.uk | alessandro.melis@port.ac.uk
}

\begin{abstract}
Through its worldwide impact, the on-going Covid-19 pandemic has fundamentally affected the way people live and experience the built environment in every country. Starting to spread in late January 2020 in Europe and in the Mediterranean Region, the threat of viral infection with the Coronavirus led to several phases of lockdowns from mid-March on until now. The limited accessibility and the safety measures during this last year have challenged dramatically the perception and the use of public space thresholds between private, semi-private and public conditions, creating new forms of temporary appropriation. The consequential paradigms of household isolation and social distancing have also contributed to the augmentation of the public space, now swinging between digital and analogue possibilities. In opposition to the former wide range of possibilities of space uses in everyday life, being subject to restricted spatial conditions under the current situation leads to new challenges on a cognitive level: the resulting change in the perception of proximity and distance, indoor and outdoor, private and public, implies an expanded use of both spaces introducing many opportunities of colonisation of private, public and semi-public appropriation creating new forms (and sometimes also old ones) of resilience. Algiers, Portsmouth and San Francisco de Campeche have been selected as case studies to observe how the lockdown was organised from the same time on in different places with distinct political approaches and public control measures, and the impact this had on the community and the use of public space in the three cities.
\end{abstract}

Keywords: public space, temporary appropriation, community, resilience, pandemic

To cite this article:

Melis, B., Lara Hernandez, J. A., Khemri, Y. and Melis, A.. (2020). Shifting the Threshold of Public Space in UK, Algeria and Mexico during the Covid-I 9 Pandemic, The Journal of Public Space, 5(3), I59-I72, DOI 10.3289|/jps.v5i3.1387

This article has been double blind peer reviewed and accepted for publication in The Journal of Public Space.

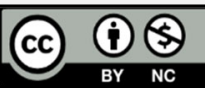
This work is licensed under a Creative Commons Attribution - Non Commercial 4.0 International License https://creativecommons.org/licenses/by-nc/4.0/ 


\section{Background of the research}

The current Coronavirus pandemic has affected the lives of everyone and signifcantly impacted the urban public space around the world undermining the conventional flow of outdoor public space activities in all countries affected by Covid-19.

As the United Nations states (2020), public spaces are key in reducing stress levels, improving mental health and wellbeing, contributing to children's development, and establishing temporary facilities. As a consequence of the lockdown measures, the "normality" of our urban lives got suspended. The latter represents the loss of access to the wider public realm and has revealed the uneven distribution of accessibility of public urban space related to a loss of social life, reduced levels of outdoor activities and a lack of informal social support networks, particularly for more vulnerable or disadvantaged people (Varna \& Oswell, 202I). However, as a result of the emerging pandemic reality, this has also given the opportunity to local communities to re-invent and re-define new spatial models in the form of temporary appropriation (TA) for comunication and interaction with people in their local environments adhering to social distancing and contributing to a more resilient model of the society. This paper is a first attempt to explore unconventional uses of public space due to the pandemic including a more flexible use of the liminal adoption of spaces between public and private, creating new forms of connection with people whilst respecting social distancing. Among these, TA is conceptualised as a form of colonisation beyond the expectation of the planning determinsm in the urban realm, emerging as a resilient response of community to crisis (Melis, Lara-Hernandez, \& Thompson, 2020). In this text, and according to the UN definition, resilience is intended as the ability of community exposed to a crisis, such as the pandemic, to resist, absorb, accommodate to and recover from its effects in a timely and efficient manner (UNISDR \& WMO, 20I2).

Spreading worldwide, Covid-19 was declared a pandemic by the World Health Organization on the II th March, 2020 (World Health Organisation, 2020a) and people worldwide were forced to remain confined to narrow ranges, within close proximity of where they lived. For instance, the severe lockdown modalities and the control of public spaces by institutions and law enforcement agencies in the Medieterranean region, especially in Italy and Spain, contrast with the laissez-faire orientation of Northern countries, like the UK and Sweden (Edwards, 2020).

UK, Algeria and Mexico are considered, here, as paradigmatic examples of contextual differences leading to a variety of community responses in terms of TA of private, semiprivate and public spaces. Utilising a participant overt observation mapping as defined by Groat and Wang (2013) in their book Architectural Research Methods in all three places, during the period March-May 2020, it has been observed that the conditions of lockdown and the response of the communities are variables of the climatic, cultural and political context.

In the section that follows, we will focus on the concept of public space and the TA in order to better understand, through categorisation of activities, its potential use as a methdology enabling the measurement of community resilience. Within the aforementioned countries, Southsea (Portsmouth, UK), El Houma (Algiers) and San Francisco de Campeche (Mexico) have been selected to carry on observations oriented to the measurement of resilience of communities through TA activities providing a new framework of community-based resilience in the times of the pandemic. These different observations of interventions in politically and culturally diverse places prove that a new 
reimagining of our public space is possible and led by the local community challenging planners and urban designers to capture this zeitgeist (Varna \& Oswell, 202I), and to involve and develop it further in the planning process of our future cities.

\section{The resilience of the public space through temporary appropriation}

Given the complexity of the concept, implying multiscale methodologies, it is not the purpose of this section nor our intention to exhaustively review such extensive literature. Rather, the aim is to acknowledge the concept within the theoretical framework which advocates that public spaces are areas of urban settlements where sociability occurs. The construction of urbanity (Lofland, 1998; Madanipour, 1998), allows accessibility to a wide range of activities and uses, involving different kinds of people and groups (Kärrholm, 2007). Authors such as Zukin (1987), Avritzer (2002) and Graham and Aurigi ( 1997 ) have highlighted also the political dimension of public space, arguing that, in democratic countries, the public spaces are crucial to fuel and maintain the democracy. The space where this conflict is more evident is in the public space, which serves as the locus of collective expressions for those who are deprived of institutional settings to disagree (Roy \& Alsayyad, 2004). Salcedo-Hansen (2002) argues that the public space is always under control and the exercise of power and, at the same time, there will always be resistance against that control. Scholars like Low (2000) and Mouffe (2007) consider that the access to public spaces where people can exercise freedom of speech and aggregation to a diverse social group sharing interest is a precondition for democracy. We agree with Jackson (2003) when she states that the social capital starts at the scale of the neighbourhood and most commonly in public spaces. McBride ( 2005, p. 102) supports this argument stating that "When we lose public space, we lose democracy". Lack of public space, or its TA, has, therefore, a series of negative effects such as loss of urban identity (Bolio Arceo, 2012), the risk of increasing levels of mental illness among the population (Evans, 2003; Jackson, 2003) or even alienation (Martínez, 20I4). The current lockdown due to Covid- I 9 has exacerbated the aforementioned negative impacts (World Health Organisation, 2020). The resilience of a public space, intended as the capacity of a system to adapt to change, is proportional to the possibility of TA. It follows that, in times of lockdown, the response in terms of community resilience is particularly dependent on the possibility of allowing forms of TA (Melis et al. , 2020).

Lara-Hernandez and Melis (2018) described the concept of TA in which the bond between people and places is enhanced. When the diversity of TA of public spaces is increased, the social sustainability is augmented, increasing community resilience, and strengthening socio-urban buffer areas in the city (Melis et al., 2020). The activities that fall within this measure of public space resilience fall into three categories: economy, leisure, and sacralisation. These are the activities which we will consider in the emerging forms of TA during lockdown, in relationship to the selected case studies, Southsea, El Houma and San Francisco de Campeche.

Having explained the concept of TA, now we will move to elucidate each of the three case studies. 


\section{Resilience of the community through temporary appropriation of semiprivate and private space: the case of Southsea, UK}

The United Kingdom was one of the last European countries to respond with appropriate measures to the spread of Covid-19 in late January 2020, which led to a partial lockdown from mid-March entering in a national lockdown on the $23^{\text {rd }}$ March, 2020 (GOV.UK, 2020).

The lockdown challenged dramatically the perception of public space thresholds between private, semi-private and public conditions and accentuating its importance for a vibrant community. "A nearby patch of green has become more precious than the trendiest address, streetscapes have revealed their naked selves without the activities that usually animate them" (Wehner, 2020). Enlarging the private space of the ground floors of buildings and connecting it to the public realm by creating semi-public spaces through TA has proven to be a successful strategy in creating a new sense of community and neighbour support and exchange.

Southsea, a cohesive neighbourhood of Portsmouth, the most densely populated city in the UK, with 5,100/ sqkm inhabitants (World Population Review, 2020), seems an ideal case study to represent extreme lockdown conditions in the UK. The main observation has regarded the resilience of outdoor spaces of the town house, which constitutes the basic unit of the urban fabric, here and everywhere in the UK. Its front yard, as a semiprivate zone, has become a social and physical buffer allowing activities previously assigned exclusively to public space.

The versatility of this space type, during the pandemic, as an opportunity to welcome the very diverse culture of the city, due to a large international university, corroborated a certain attitude towards laissez-faire, as well. According to the TA categories, the following activities have been detected: a) trade including the delivery of online purchases and exchange or sale of second-hand objects and plants; b) leisure including exercise and relax; c) social activities including neighbour barbeques in residential parking lots and celebrations like "Clap-for-Carers" on Thursday evenings, as well as concerts and visiting (see Figure I).

Among the TAs of both the front yards, walkways and the streets, the celebration of Veterans Day on May 8th, consistent with the reccomendations of the British Government, which seemed to be rarely perceived as prescriptions by the citizens, well rapresented the British motto "Keep Calm And Carry On".

Deriving from the poster produced by the British Government in 1939 in preparation for World War II, particularly felt here in the city of the Royal Navy and the D-Day boarding, this attitude has been revitalised as a sort of flag during the Covid-19 emergency.

One hour of outside-activity in green urban areas was widely supported and encouraged, and, when not possible in public space, the backyards have been used as a compensation by households. Also, the centrality of parks in the British way of living, as a symbol of urban cultural inclusiveness, has not been neglected during the lockdown, thanks to limited access restrictions with a nearly imperceptible controlling presence (see Figure 2). Road closure at Southsea seafront encouraged walking, biking and other outdoor activities, improving mobility and safety in this area.

A limitation of these observations, when compared with those shown by the media in the cities of the Midlands or the north of England, is that Portsmouth is one of the English cities with the greatest solar radiation. In addition to the extraordinary 
compactness of the residential fabric, such an enviable climatic condition has allowed spatial opportunities, which, despite the Victorian flavour of the architecture, and albeit occasionally, recall common uses of public space in the Mediterranean region (as in the case of El Houma, described below).

Beyond the constraints, which with the advent of vaccinations, at the time of writing, should fade away, a positive aspect of the public space issue in the south of the United Kingdom in times of pandemic is its transformative, plastic and of diversity potential, which we hope will remain a heritage of the communities also for the future.
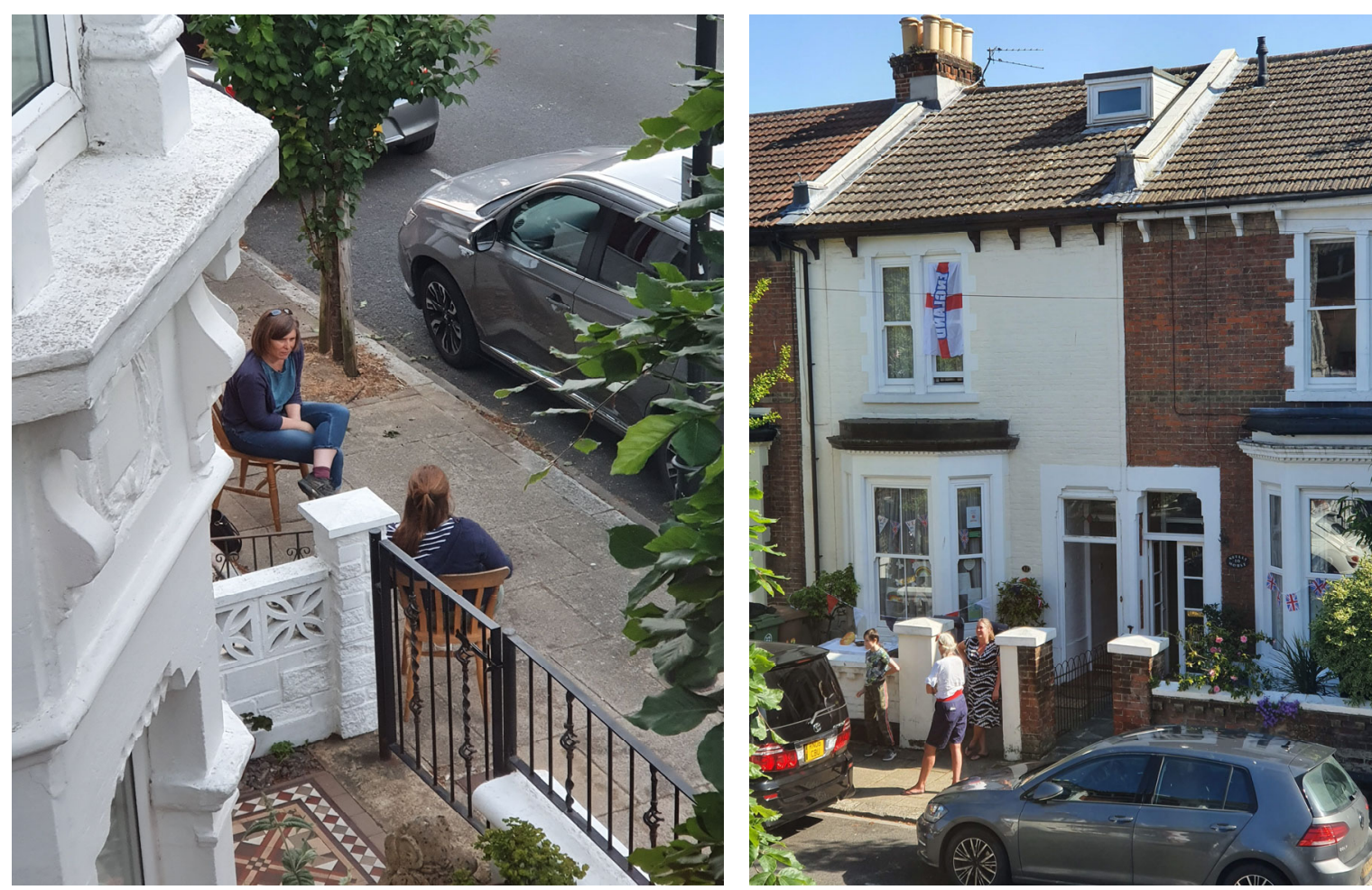

Figure I: Neighbours socially distanced chat and neighbours celebrating Veterans Day in May 2020 in Southsea. Source: B. Melis.

\section{The resilience of communities and the temporary appropriation of public space: The case of El Houma}

Given the strategic position that Algeria occupies as a Mediterranean country, and having a busy schedule of flights to and from Europe, the country witnessed the spread of the pandamic in February. Following the surge of Covid-19 infection in Europe, the country rushed into closing its borders and imposing a strict lockdown protocol all over the country. In addition to closing the borders, this protocol, in addition to other measures, precisely suspended all informal markets and restricted people from leaving their houses and gathering in public spaces, something which Algerians are accustomed to do.

Socialising in Algiers' public spaces is pivotal in the lifestyle of Algerians, which forms the main basis of the concept of El Houma. The El Houma is a term specific to North Africa and is used to refer to a neighbourhood where frequent social use of space takes 
place, engendering an organic urban life (Khemri et al., 2020). It is a socio-spatial product, defined by the intensity of social interactions and is formed of intricate social relations between residents (Dris, 2005; Grangaud, 2009). El Houma represents local social life of people in a neighbourhood, and the practices that happen in El Houma engender social dynamics, which, in turn, promote social cohesion, sense of community and strong feelings of trust and solidarity among neighbours (Khemri \& Melis, 202I). These spatial dynamics are the main drivers into raising awareness among residents to consider fighting disruptions as their collective duty and inspire local resilience strategies within the neighbourhood.

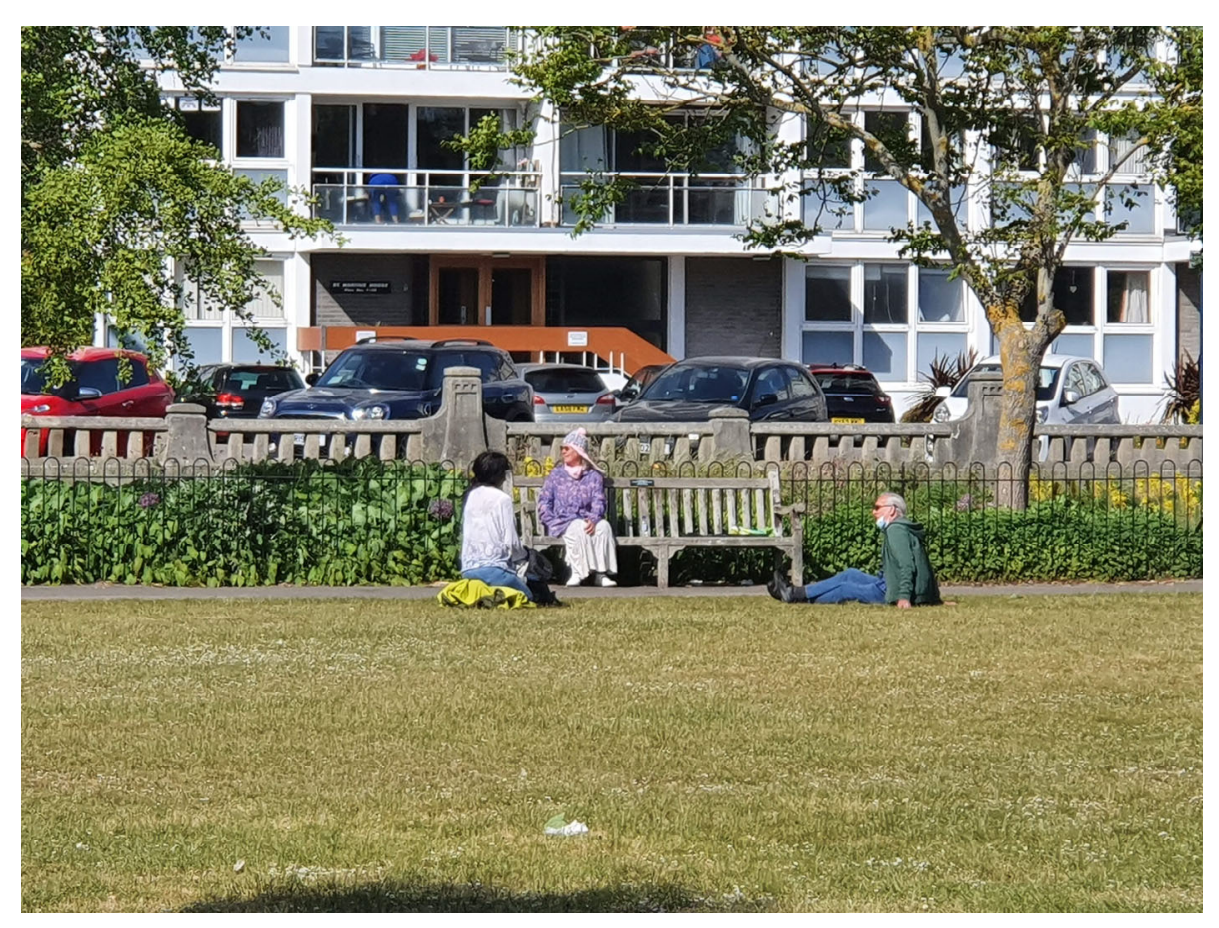

Figure 2: People chatting socially distanced in a public park in Southsea. Source: B. Melis.

El Houma, as any other resilient urban system, is formed of a combination of tangible (built environment) and intangible (culture, social life and lifestyle) aspects. People would consider their area of living as El Houma only when the built environment allows frequent and enduring social use of space, while performing various activities such as chatting, resting, reading, playing card games or sports activities, eating and drinking, and informal street vending (Khemri \& Melis, 202I).

A series of observation taking place in Algiers' El Houma, as a case study here, showed a strong sense of belonging among residents, which allows various forms of urban spaces uses such as the occupation of public spaces of El Houma to celebrate weddings, whereas the lack of resources and money to afford renting a hall is considered a disruption that people within El Houma collaborate to overcome. For instance, members of El Houma ferquently collaborate to organise a wedding, set the tables in the public space and occupy the dance floor during the ceremony (see Figure 3). The strong sense of community and sense belonging within El Houma grant its members the right to use the space freely to perform their socio-cultural life and deem all activities appropriate. Similar to occupying a public space to organise a wedding 
ceremony, people would use it to play football, marble games or any other leisure activities, and, when a member of El Houma dies, neighbours would occupy the public space to organise the funeral, by gathering next to the deceased's house to show support and solidarity. Another important activity that contributes to urban life, and, thus, El Houma, is informal commerce activity, whereas a lot of people rely on street vending as their source of income, others equally benefit from this activity, as it is perceived affordable to all social classes.

Before the pandemic and the enforcement of the lockdown, these activities took place in various expressions of the urban landscape, in the narrow streets or the wall fountains of the Casbah (the Algerian medieval medina), or in the arcades, planted boulevards and public spaces of the city. However, unlike the UK, the Algerian government imposed strict lockdown and curfew on the country, like most countries around the world did, which restricted people from going out and socialising in urban areas.

Public spaces under the threat of Covid- 19 lowered significantly the degree of sociability between people, making spaces lifeless and sending signs of unsafety, something, which neighbourhoods that embody El Houma have never undergone.

Nonetheless, some people had to improvise to continue practising their daily life outdoor. Even though it was illegal to go outside, some people used roof terraces of buildings and narrow streets to spend time outside. Small public spaces in residential areas were transformed into a mosque to perform prayer on the day of Eid al-Fitr, which is a religious holiday celebrated by Muslims worldwide at the end of Ramadan. This activity is usually performed indoors; however, at the time mosques were closed because of Covid-19, so people gathered in a public space to perform prayer, while observing social distancing (see Figure 4).

Due to different climatic, cultural and political contexts, an opposite spatial logic of TA to that observed in England prevails in El Houma. Before and during the pandemic emergency, the community frequently gather in the shade of the public interstitial space between the buildings, with several spatial practices.
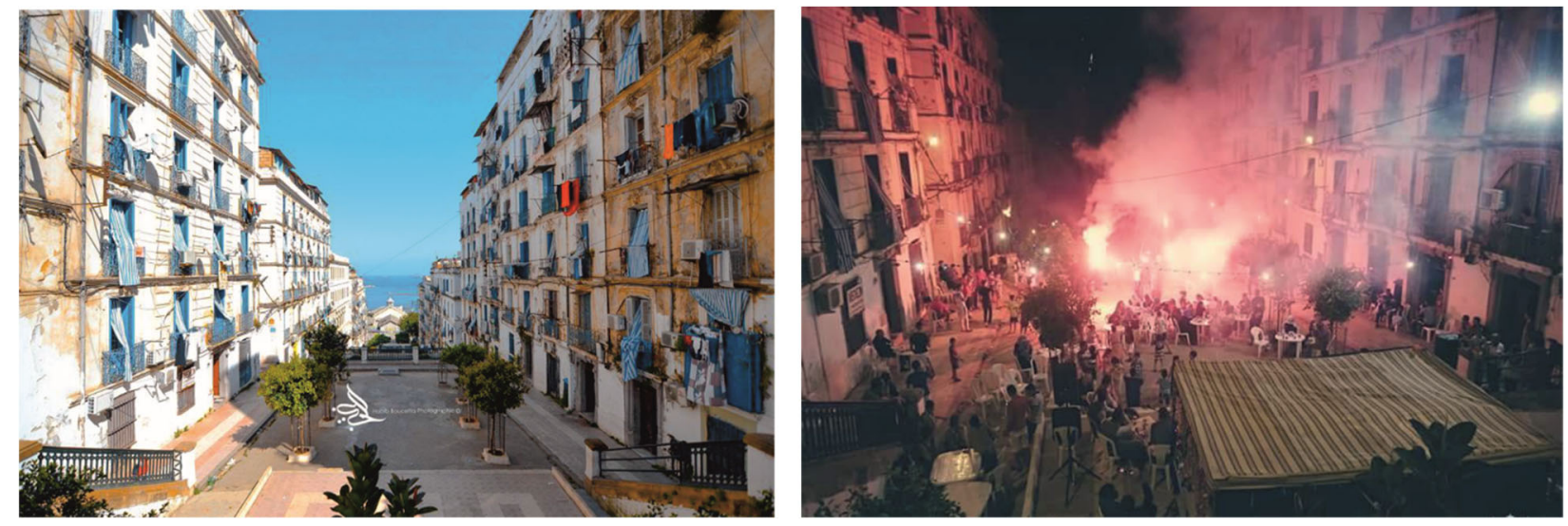

Figure 3: The impact of Covid- I 9 can cancel the possibility of having various activities in public spaces of El Houma, such as celebrating weddings. Source: Boucetta. 


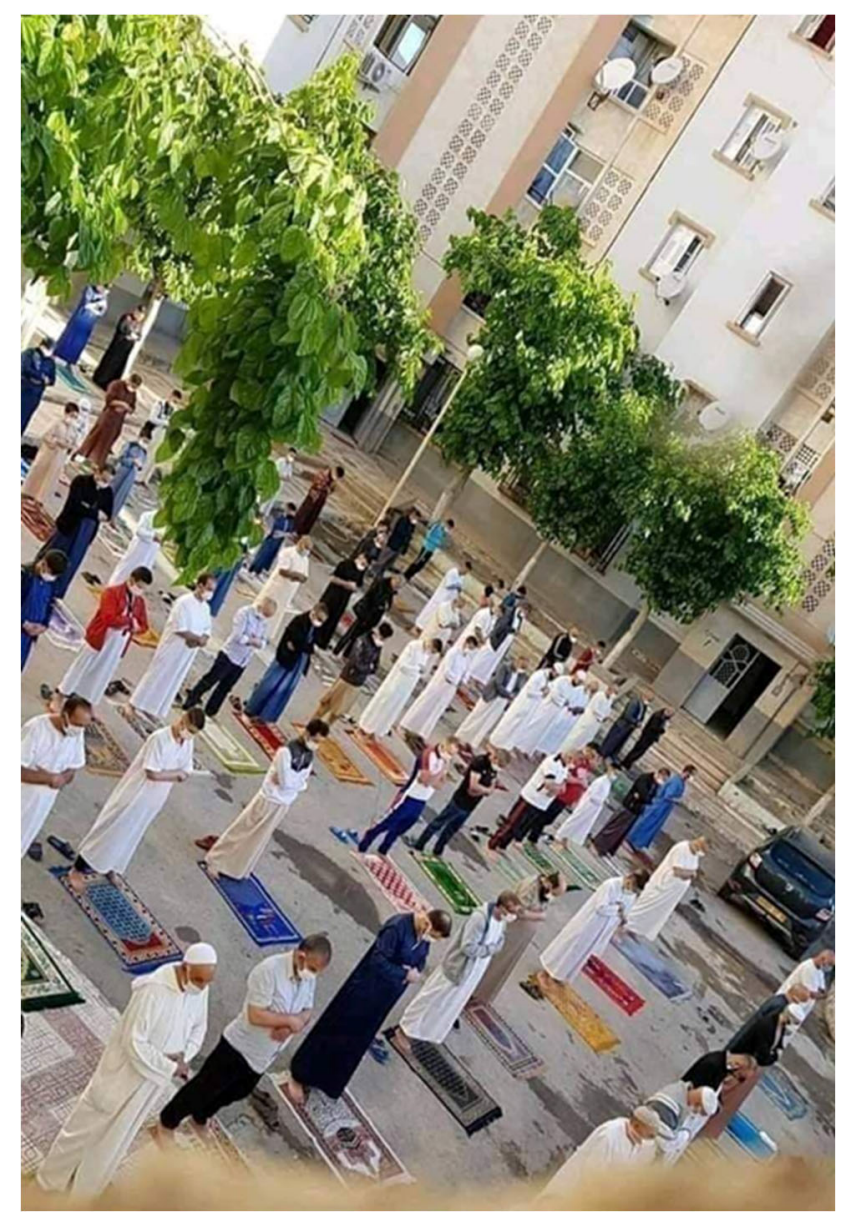

Figure 4: Public space is used to perform prayer on Eid Al-Fitr in 2020.

Source: Ziari, 2020 retrieved from: https://www.annasronline.com/index.php/2014-08-I7-|3-22-10/20 I408-27-| 8-45-22/I51028-2020-05-26-10-33-I4

\section{The resilience of communities and the temporary appropriation of public space: The case of San Francisco de Campeche}

During last year, 2020, the pandemic was very challenging for communities worldwide. The lockdowns were a common measure to avoid the spreading of the disease, starting from Asia, then Europe and lastly in America. Such measures severely disturbed the life in cities, starting from disruption of supply chains till protests and social movements, including conspiracy theories. For instance, in February 2020, the Mexican government reported that 12 million formal jobs were lost within two months of lockdown due to the pandemic (Redacción, 2020).

Each city as a socio-ecological system, depending on their resiliency capacity, has the ability to auto regulate itself and overcome disturbances (Holling, 1973; Yamagata \& Maruyama, 2016). TA of public spaces as described by Lara-Hernandez and Melis (2018) plays a significant role towards increasing resilience. To illustrate the latter, we will take the case of San Francisco de Campeche presented last August by Lara-Hernandez (2020): A Year without Public Space under the Covid- 19 Pandemic Series organised by City, Space and Architecture. 
San Francisco de Campeche is the city capital of the state of Campeche (Mexico), having approximately a quarter of a million inhabitants located in the Yucatan peninsula in Mexico. Despite that the state of Campeche was one of the less affected in terms of Covid-19 infections within Mexico, starting from May 2020, due to lockdown restrictions, access to the central market and public transportation was very limited (Figure 5). Thus, making it extremely hard for people living outside walking distance from the central market to get their daily goods.
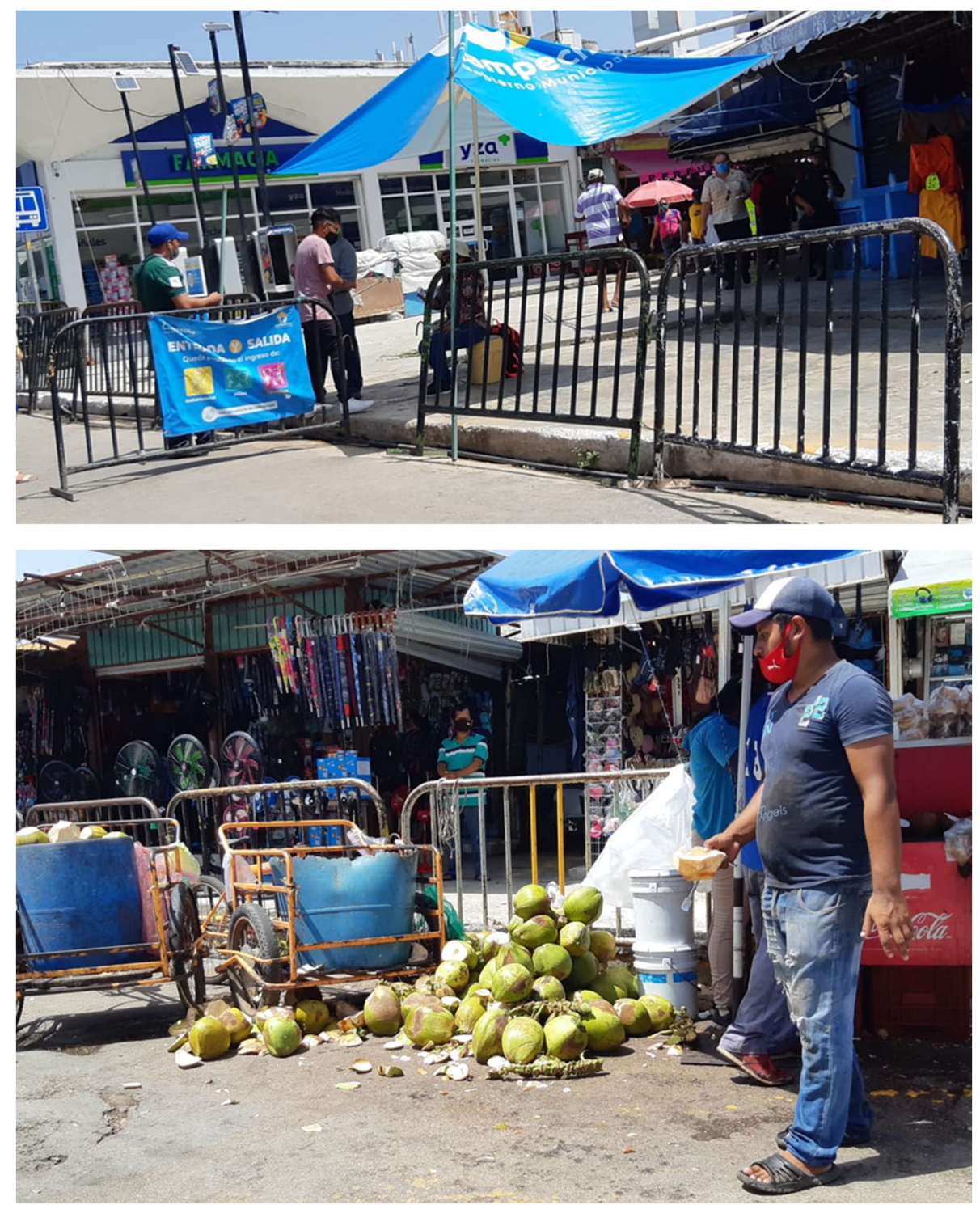

Figure 5: Fence around central market in San Francisco de Campeche. Source: J.A. Lara-Hernandez, 2020.

Nevertheless, such circumstances propitiate the emergence of several street vendors in different areas of the city, each of them offering different type of products, reflecting a wide diversity of design configuration (see 
Figure 6). In terms of design, the street vendors configured their vending stands following design principles illustrated by Lara-Hernandez (20I3) to create the so called "space of contact", a term introduced by Choay (200I). Such design principles include i) the availability of shade, ii) a view opening degree ranging from 70 to I 20 degrees, iii) available seating places and lastly iv) the possibility to see and be seen by others.

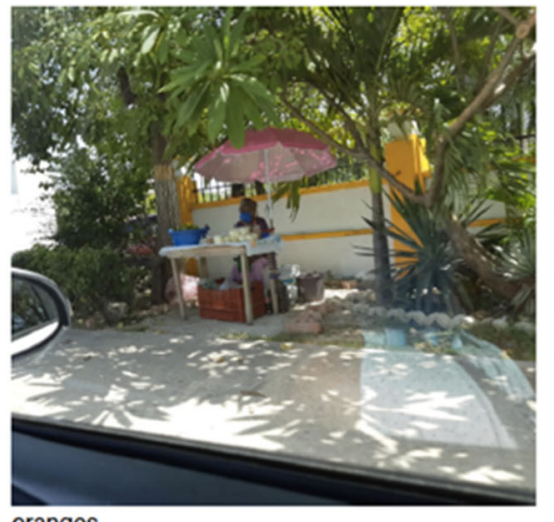

oranges

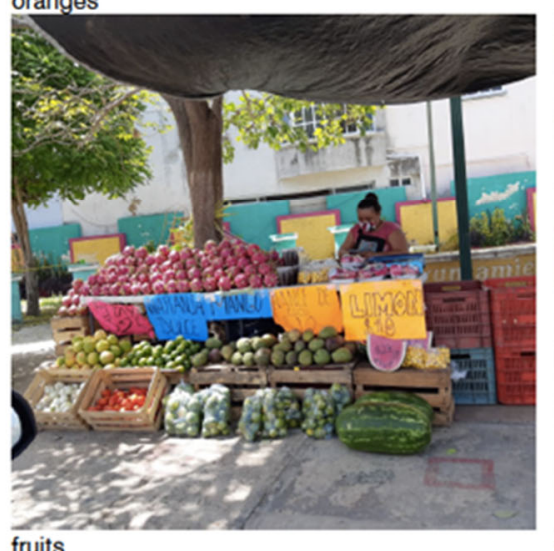

fruits
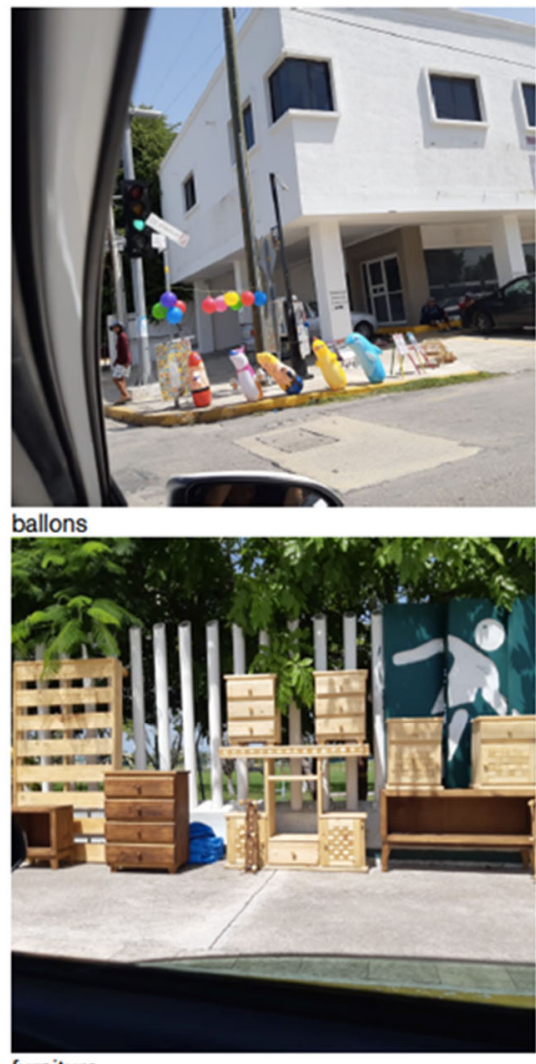

furniture
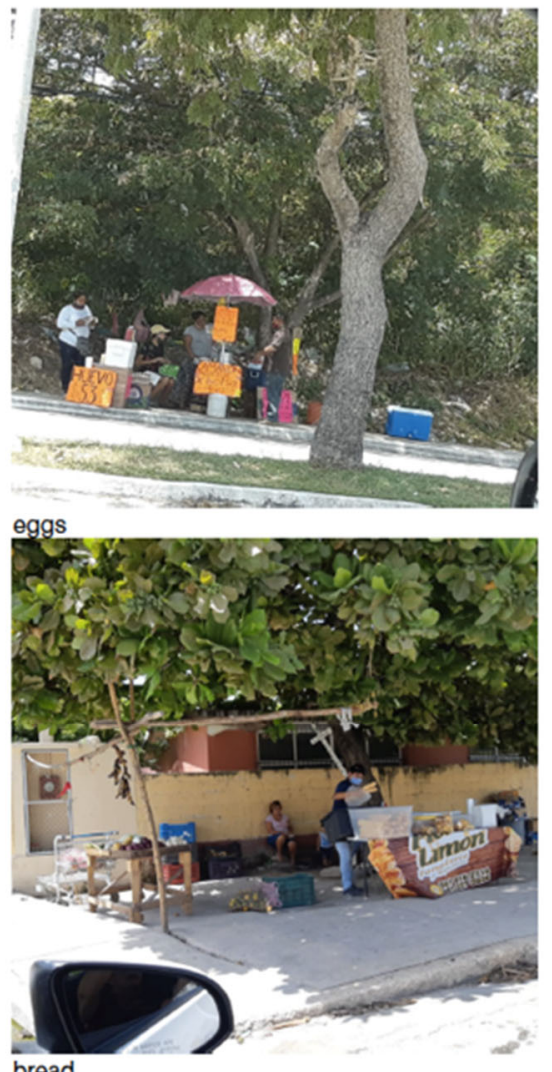

bread

Figure 6: Street vendors temporary appropriating the public space. Source: Photographed by J.A. LaraHernandez, 2020.

In terms of planning, the TA emerging in the area was mapped through the street vendors (see Figure 7). What is interesting about the data in Figure 6 is that there is a clear pattern of the location of vending stands. Each black dot represents a street vendor and the dashed line in circle around it shows a radius of $200 \mathrm{~m}$ walking distance. Thus, to some extent, the emerging TA of the street vendors supplied the immediate needs of people who could not go to their usual shopping to the central market. Looking at the city as a socio-ecological system this is a clear example of an unplanned resilience strategy to halt the negative effects of the lockdown, minimising the risk of Covid-19 contagion. Additionally, the latter is a clear example of what Melis, LaraHernandez, and Foerster (2020) described as an architectural exaptation at the level of public space, which increases the level of resiliency of a place. 

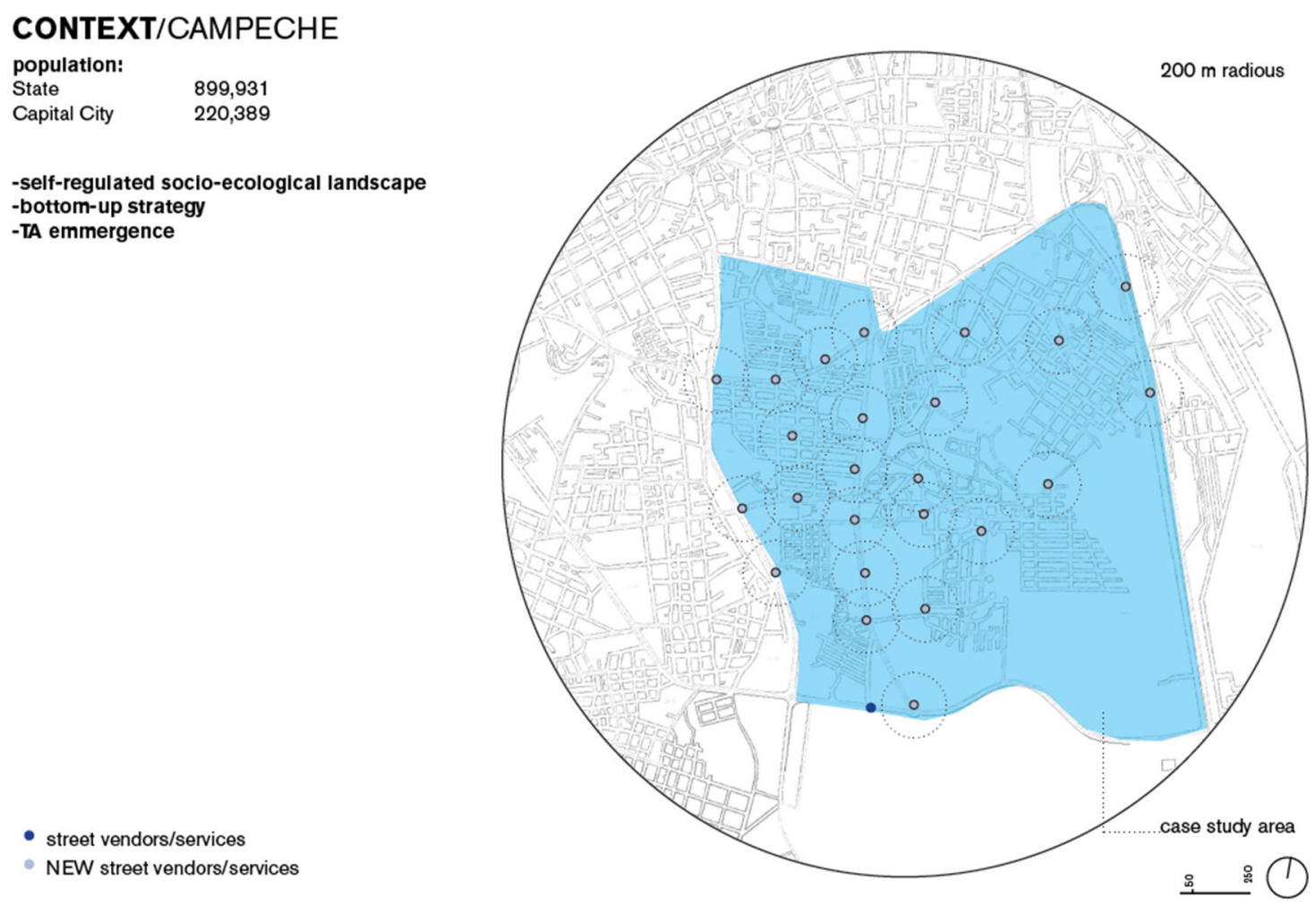

Figure 7: Street vendors map. Source: Lara-Hernandez, 2020.

\section{Discussion and Conclusion}

The Covid-19 pandemic lockdown evolved in a new context of urbanity, giving a new meaning to both public and semi-public space. But how do we ensure that we get the public space we want and need, whether that is green space that helps us stay healthy, or the shared space that makes our cities feel vibrant and alive?

As expected, the conventional resilience strategy has been less effective during the lockdown period, when social distancing was required. In opposition to the wide range of possibilities in everyday life, the current situation, being subject to restricted spatial conditions, has led to new challenges, on a cognitive level.

From the comparison, it emerges that some differences in the use of public and semipublic space in different countries, in times of pandemics, manifest themselves in a different balance of the categories of activities that represent TA. In Algiers, the activities of mutual support of the families of the community prevail (even though strongly depending on the spatial dimension and feature of the built environment: Medina vs Modern), in Mexico, the urgency corresponds to a greater presence of basic commercial activities, while, in England, the barriers between public and private spaces are thinning, which, in some ways, make the use of the street more similar to that of the Medina.

However, in the English case, some forms of appropriation of public space take on a symbolic and identity value in support of national institutions, such as the NHS. It is as if, in this case, the lack of social cohesion based on extended family models, was compensated by a strong sense of belonging to the national community. 
Certainly, the case of Southsea/Portsmouth is particular, given that it is a city proud of its political past as the centre of military actions (Normandy landings) for the liberation of democratic Europe from Nazi-fascist tyranny. Therefore, the push to occupy public space is probably felt as a demonstration of support for the national government (or, in this case, an emanation of it (NHS).

During lockdown in Southsea, new individual or family uses of private space have included public functions previously designated to exclusively public space in open urban areas. In Algiers, instead, forms of occupation of the public space prevailed for group activities and private individuals, which were then ratified by the sense of solidarity which characterizes the sense of community of El Houma. While, in the first case, unconventional uses of private space have also been identified, compared to prepandemic normalcy, in the second case the TA of public space, increased or decreased, is, however, in line with the characteristics of community cohesion.

This fundamental difference in dealing with the virus reflects the community orientation of El Houma and the more individualistic orientation of British neighbourhood which cannot be restrited by legislative decrees and self-certification. Whereas the case of San Francisco de Campeche, as an example of self-regulation of the city as a socio-ecological system, reinforcing theoretical models of resilience in the ecnomic dimension of the urban landscape, is evident (Stockholm Resilience Center, 20I4).

The flexibility of external private space of the houses in Southsea, San Francisco de Campeche and the streets of El Houma afforded as many opportunities as possible of colonisation of private by new forms (sometimes also old ones) of public and semipublic appropriation without compromising the multi-dimensional vocation of the three of them.

According to the observations in all three scenarios, the resulting change in the perception of proximity and distance, indoor and outdoor, has implied an expanded use of public spaces, which can turn into significant improvement of the post-pandemic cities.

What can we learn about public space use and planning for the future?

The pandemic has taught us the importance of public spaces as arenas for social interaction, whereas people spend most of their time in public spaces during the pandemic, because of working from home and suspension of indoor coffee shops, restaurant and other leisure centres. Therefore, it is important to rethink the design of public spaces, by adapting their design to allow social distancing in otder to provide a safe environment for people. The design of more public spaces in neighbourhoods is vital to ensure equal access for all residents and prevent spaces from overcrowding to reduce teransmission risk. Wider pavements and streets are also necessary, as the observations in the three case studies showed how people occupy those spaces to socialise. It is necesary to of the streets as more a public space rather just a mere infrastructure for transportation purposes. Other aspects of urban design for the future could be considered, such as the conversion of car parks into public space, designing buildings with balconies to allow consistent contact and exchange with the outside world, and ensuring natural ventilation in buildings. We need to re-think the way in which we engage with the space, utilising divergently and creatively the public spaces in our cities. 


\section{References}

Avritzer, L. (2002). Democracy and the Public Space in Latin America. Princeton University Press.

Bolio Arceo, E. (20I2). Urban Transformations and Place-Identity: The case of Merida. Oxford Brookes University.

Edwards, C. (2020, May 20). As Europe comes out of lockdown, what lessons can be learned from Sweden? The Local SE. Retrieved from https://www.thelocal.se/20200520/as-europecomes-out-of-lockdown-what-lessons-can-be-learned-from-sweden

Evans, G. W. (2003). The built environment and mental health. Journal of Urban Health: Bulletin of the New York Academy of Medicine, 80(4), 536-555. https://doi.org/ I0. I093/jurban/jtg063

GOV.UK. (2020). Speech: Prime Minister's statement on coronavirus (COVID- 19): 23 March 2020.

Graham, S., \& Aurigi, A. (1997). Virtual cities, social polarization, and the crisis in urban public space. Journal of Urban Technology, 4(I), 19-52. https://doi.org/I 0. I080/I0630739708724546

Groat, L., \& Wang, D. (20I3). Architectural research methods (Second). John Wiley \& Sons, Inc.

Holling, C. S. (1973). Resilience and Stability of Ecological Systems. Annual Review of Ecology and Systematics, 4(I), I-23.

Jackson, L. E. (2003). The relationship of urban design to human health and condition. Landscape and Urban Planning, 64(4), I9I-200. https://doi.org/I 0.10I6/S0I69-2046(02)00230-X

Kärrholm, M. (2007). The materiality of territorial production: A conceptual discussion of territoriality, materiality, and the everyday life of public space. Space and Culture, 10(4), 437453. https://doi.org//0.1/77//20633/207304356

Khemri, Y. M., \& Melis, A. (202I). Achieving community resilience through informal urban practices: the case of El Houma in Algiers. In A. Di Raimo, S. Lehmann, \& A. Melis (Eds.), Informality Now: Informal Settlements Through the Lens of Sustainability. Routledge. Taylor \& Francis Group.

Khemri, Y. M., Melis, A., \& Caputo, S. (2020). Sustaining the Liveliness of Public Spaces in El Houma through Placemaking. The Journal of Public Space, 5(I), I29-I52.

Lara-Hernandez, J. A. (20I3). Urban Revitalization. Domus Academy.

Lara-Hernandez, J. A., \& Melis, A. (20I8). Understanding the temporary appropriation in relationship to social sustainability. Sustainable Cities and Society, 39C, I-I4. https://doi.org//0.1016/j.scs.2018.03.004

Lara-Hernandez, J. A. (2020). Emerging Temporary Appropriation: Post-2020 Scenario. In L. Bravo (Ed.), 2020: A Year without Public Space under the COVID-19 Pandemic: Tactical urbanism as a crisis response and as mobiliser for systemic change. City Space Architecture. Retrieved from https://youtube.com/playlist?list=PLrcH8PpHiZgLr7nJTwoKWwcm42GRSO9tn

Lofland, L. H. (1998). The public realm: Exploring the city's quintessential social territory. Transaction Publishers.

Madanipour, A. (1998). Social Exclusion and Space. The City Reader, I58-165. https://www.dawsonera.com.ezp.sub.su.se/abstract/9780203869260

Martínez, E. (20I4). Configuracion urbana, hábitat y apropiación del espacio. Scripta Nova. Revista Electrónica de Geografia y Ciencias Sociales, 493(33), I-20.

McBride, K. (2005). Brave New Neighborhoods: The Privatization of Public Space. International Journal of Urban and Regional Research. 29(4), I00 I-1003. https://doi.org/I 0. I I I / j. I 4682427.2005.00635_4.x

Melis, A., Lara-Hernandez, J. A., \& Foerster, B. (2020). Learning from the biology of evolution: Exaptation as a design strategy for future cities. In A. Ghaffarianhoseini, A. Ghaffarianhoseini, \& N. Naismith (Eds.), The 54th International Conference of the Architectural Science Association (Issue November, pp. 680-688). The Architectural Science Association (ANZAScA).

Melis, A., Lara-Hernandez, J. A., \& Thompson, J. (2020). Temporary Appropriation in Cities: Human Spatialisation in Public Spaces and Community Resilience. Springer Nature Limited. https://doi.org// 0.1007/978-3-030-32/20-8

Mouffe, C. (2007). Public spaces and democratic politics. LAPS. 
Murphy, K,D (200I). Review: The Invention of the Historic Monument by Françoise Choay, Lauren M. O'Connell. The Journal of the Society of Architectural Historians, 6(2), 248-249. https://doi.org// 0.2307/99/857

Redacción. (2020, July 9). Se perdieron en México más de 12 millones de empleos en dos meses. El Financiero | Bloomberg. https://www.elfinanciero.com.mx/economia/se-perdieron-enmexico-mas-de-12-millones-de-empleos-en-dos-meses-segun-datos-de-banxico

Roy, A., \& Alsayyad, N. (2004). Urban informality: Transnational perspectives from Midle East, Latin America and South Asia. Lexington Books.

Salcedo-Hansen, R. (2002). El espacio público en el debate actual: Una reflexión crítica sobre el urbanismo post-moderno. EURE (Santiago), 28(84), I-I I. https://doi.org/S0250?716I200200840000 I

Stockholm Resilience Center. (20I4). What is resilience? An introduction to social-ecologial research. Retrieved from http://www.stockholmresilience.org/download/I8.5ea7abe0 I39d0dada52 I ac/resilience_sum mary_lowX.pdf

UNISDR, \& WMO. (2012). Disaster risk and resilience. UN System Task Team on the Post-2015 UN Development Agenda. United Nations Office for Disaster Risk Reduction. World Meteorological Organization, May.

United Nations. (2020). COVID-19 in an Urban World. Policy Brief: July.

Varna, G., \& Oswell, D. (202I). Towards a stronger quality-of-place agenda in the 'new normal.' Town Planning Review, 92(I), I07-I I4. https://doi.org/I0.3828/tpr.2020.7I

Wehner, P. (2020). Future of UK Cities: Unlocking the power of public space. EGI, November II.

World Health Organisation. (2020). Naming the coronavirus disease (COVID-19) and the virus that causes it. Retrieved from https://www.who.int/emergencies/diseases/novel-coronavirus2019/technical-guidance/naming-the-coronavirus-disease-(covid-20/9)-and-the-virus-thatcauses-it

World Population Review. (2020). United Kingdom Population 2020 (Demographics, Maps, Graphs). Retrieved from https://worldpopulationreview.com/countries/united-kingdom-population/

Yamagata, Y., \& Maruyama, H. (2016). Urban Resilience: A Transformative Approach. In Y. Yamagata \& H. Maruyama (Eds.), Advanced Sciences and Technologies for Security Applications. Springer Nature Switzerland AG. https://doi.org/I0.1007/978-3-3 I9-398I2-9

Zukin, S. (1987). Gentrification: Culture And Capital In The Urban Core. Annual Review of Sociology, I3(I), I29-147. https://doi.org/I0.1 146/annurev.soc.13.I.129 